\title{
ISU SOSIAL PASCABENCANA ALAM: STUDI KASUS PENJARAHAN DI KOTA PALU MELALUI PENDEKATAN PINHEIRO PRINCIPLES DAN PSIKOLOGI SOSIAL
}

\section{NATURAL POST-DISASTER SOCIAL ISSUES: CASE STUDY OF LOOTING IN PALU CITY BASED ON PINHEIRO PRINCIPLES AND SOCIAL PSYCHOLOGY}

\author{
Milawaty \\ Pusat Pelatihan dan Pengembangan dan Kajian Manajemen Pemerintahan \\ Lembaga Administrasi Negara \\ Jl. Raya Baruga Nomor 48, Antang, Makassar \\ E-mail: mylaffayza@ymail.com
}

Naskah diterima tanggal 24 November 2020. Naskah direvisi tanggal 29 Desember 2020.

Naskah disetujui tanggal 31 Desember 2020

\begin{abstract}
Abstrak
Pada 27 September 2018, Sulawesi Tengah tertimpa bencana alam gempa bumi, tsunami, dan likuifaksi. Bencana tersebut mendorong munculnya kekacauan berupa penjarahan massal yang berpusat di Kota Palu pada 29 September hingga 7 Oktober 2018. Penelitian ini mencoba melihat lebih jauh penjarahan yang terjadi pascabencana alam di Kota Palu dari sudut pandang Pinheiro Principles dan pendekatan psikologi sosial. Tujuan penelitian adalah menganalisis motif penjarahan pascabencana alam di Kota Palu, dan meninjau upaya-upaya yang telah dilakukan pemerintah dalam mengatasi penjarahan yang terjadi. Penelitian dilaksanakan menggunakan data primer dan sekunder yang kemudian dianalisis dengan metode kualitatif deskriptif. Potret penjarahan dianalisis melalui pendekatan psikologi sosial, sementara peran pemerintah mengatasi penjarahan ditinjau berdasarkan Pinheiro Principles pada masa tanggap darurat. Hasil penelitian menunjukkan bahwa motif penjarahan di Kota Palu pascabencana secara garis besar didasarkan pada dua hal, yaitu drives dan incentives. Drives didorong oleh timbulnya keinginan untuk memenuhi kebutuhan pangan, sementara incentives dipengaruhi oleh kondisi dan situasi tertentu dan menjadi penguat melakukan penjarahan. Upaya yang telah dilakukan pemerintah untuk mengatasi penjarahan yang terjadi pascabencana alam pada 27 September 2018 di Kota Palu dilakukan dalam dua bentuk sesuai UU Nomor 24 tahun 2007 tentang Penanggulangan Bencana, yaitu penjaminan pemenuhan hak masyarakat, dan perlindungan masyarakat dari dampak bencana.
\end{abstract}

Kata Kunci: motif, drives, incentives, penjaminan, perlindungan

\begin{abstract}
On 27 September 2018, Central Sulawesi was hit by a natural disaster, an earthquake, tsunami and liquefaction. The disaster led to chaos of mass looting centered in Palu City from September 29 to October 7 2018. This research tries to look further the looting after the natural disaster in Palu City from the perspective of the Pinheiro Principles and social psychology approaches. The purpose of this research is to analyze the motives of looting after the natural disaster in Palu City, and to review the efforts have been made by the government in dealing with the looting. The research was using primary and secondary data which were then analyzed using descriptive qualitative methods. The portrait of looting is analyzed through a social psychological approach, while the role of the government in dealing with looting is reviewed based on the Pinheiro Principles during the emergency response period. The results showed that the motive for looting was largely based on two things; drives and incentives. Drives are driven by the desire to meet food needs, while incentives are influenced by certain conditions and situations and become reinforcing looting. The efforts that the government has made to deal with looting that occurred after the natural disaster on September 272018 in Palu City was carried out in two forms according to
\end{abstract}


Law Number 24 of 2007 concerning Disaster Management; guaranteeing the fulfillment of community rights, and protecting the community from the impact of disasters. .

Keywords: motives, drives, incentives, guaranteeing, protecting .

\section{PENDAHULUAN}

Salah satu bencana yang tergolong besar di Indonesia dan terjadi di tahun 2018 adalah bencana alam di Sulawesi Tengah. Secara umum, letak Sulawesi memang kurang menguntungkan karena terletak dan - dalam kumpulan artikel gempa oleh Majalah Tempo, 2013, dinyatakan - terbentuk oleh pertemuan tiga lempeng, yaitu lempeng Eurasia, lempeng Indo-Austraia dan lempeng Samudera Pasifik, serta satu lempeng kecil; lempeng Filipina. Interaksi ketiga lempeng ini mengakibatkan tatanan tektonik yang rumit disertai dengan kegiatan gempa yang cukup tinggi akibat adanya pergerakan dan atau tabrakan sehingga menimbulkan tekanan dan patahan. Sompotan (2012) bahkan menganalogikan Pulau Sulawesi seakan-akan dirobek oleh berbagai sesar, seperti Sesar Palu-Koro, Sesar Poso, Sesar Saddang, Sesar Matano, Sesar Lawanopo, Sesar Walanae, Sesar Gorontalo, Sesar Batui, Sesar Tolo, Sesar Makassar, dan Sesar Sula.

Sesar Saddang, Sesar Gorontalo, Sesar Matano, dan Sesar Palu-Koro merupakan empat sesar besar yang mengelilingi Sulawesi. Dari keempatnya, sesar Palu-Koro lah yang paling aktif di Sulawesi, bahkan di Indonesia. Sesar ini membujur utara-selatan, diperkirakan bermula di Laut Sulawesi hingga Teluk Donggala sepanjang $500 \mathrm{~km}$. Sesar ini berlanjut di darat hingga sepanjang 250 km. Memanjang dari Donggala, Kota Palu, membelok ke tenggara melewati Taman Nasional Lore Lindu, sampai Teluk Bone.

Sesar Palu Koro inilah yang pada 28 September 2018 lalu bergerak dan menghantam Provinsi Sulawesi Tengah dalam bentuk gempa berskala 7.2 SR dengan episenter -0.2 LS dan 119.89 BT $26 \mathrm{Km}$ Utara Kabupaten Donggala dan 80 $\mathrm{Km}$ barat laut Kota Palu berada pada kedalaman $10 \mathrm{Km}$. Kota Palu menjadi satu dari empat kabupaten kota yang terdampak langsung gempa, selain Kabupaten Sigi,
Kabupaten Donggala, dan Kabupaten Parigi Moutong. Gempa 28 September 2018 melengkapi ribuan gempa bumi yang terjadi sepanjang 2010 di Kota Palu. Sebelumnya, gempa-gempa ekstrim yang berdampak merusak di Kota Palu diantaranya adalah kejadian gempabumi pada tahun 1907, 1909, 1927, 1938, 1968, 1998, 2005, dan tahun 2012.

Dampak dari gempa 2018 tersebut berimbas pada munculnya tsunami yang kemudian diikuti oleh likuifaksi. Tsunami terjadi dengan titik tertinggi 11,3 meter dengan kecepatan $800 \mathrm{~km} / \mathrm{jam}$ terjadi di Kelurahan Tondo, Palu Timur. Gelombang tsunami tersebut menerjang pantai, menghantam pemukiman, hingga gedunggedung dan fasilitas umum. Beberapa saat setelah puncak gempa terjadi muncul gejala likuifaksi yang memakan korban jiwa dan material. Dua lokasi yang paling nyata mengalami bencana ini adalah Kelurahan Petobo dan Kelurahan Balaroa lingkungan Perumnas. Kelurahan Balaroa terletak di tengah sesar Palu-Koro, saat terjadi likuifaksi, terjadi kenaikan dan penurunan muka tanah. Beberapa bagian naik sampai 2 (dua) meter, dan beberapa bagian amblas 5 (lima) meter sehingga bangunan amblas bagai terhisap ke dalam tanah. Di Petobo, ratusan rumah tertimbun lumpur hitam dengan tinggi 3-5 meter, terjadi setelah gempa, tanah di daerah tersebut dengan cepat berubah menjadi lumpur yang dengan segera menyeret bangunan di atasnya.

Data korban jiwa yang berhasil dihimpun Badan Penanggulangan Bencana Daerah Kota Palu mencatat 3.194 orang. Data tersebut mencakup jiwa meninggal, jiwa hilang, dan korban dikuburkan massa. Sementara dari detiknews, catatan akhir tahun BNPB angka korban yang meninggal sebanyak 2.101 jiwa. Sebanyak 1.727 jiwa diantaranya ada di Kota Palu, 188 jiwa di Sigi, 171 jiwa di Donggala, 15 jiwa di Parigi Moutong dan 1 jiwa di Pasangkayu. Adapun korban hilang 
sebanyak 1.373 jiwa, dan korban luka 4.438 jiwa (Damarjati dalam m.detik.com, 27 Desember 2018). Korban pengungsi juga tidak kalah banyaknya. Kota Palu mencatat jumlah pengungsi sebanyak 40.738 orang yang tersebar di 127 titik pengungsi. Banyak sarana prasarana pemerintahan yang rusak, bahkan hilang. Bandara Mutiara Sis A Jufri Palu ditutup akibat retaknya landasan pacu sejauh 500 meter, menara ATC rusak dan lantai empat bangunan bandara rubuh, jembatan kuning dekat Pantai Talise patah, kubah Masjid Baiturrahman roboh, akses jalan darat terputus, Hotel Roa-roa roboh, banyak tiang listrik yang jatuh, aspal jalanan retak dan patah, dan tak terhitung bangunan roboh rusak, bahkan hilang tersapu tsunami dan likuifaksi. Secara umum, total penilaian kerusakan dan kerugian pascabencana gempa bumi, tsunami, dan likuifaksi di Kota Palu sebesar Rp. 6.982.073.629.477,- (enam triliun sembilan ratus delapan puluh dua miliar tujuh puluh tiga juta enam ratus dua puluh sembilan ribu empat ratus tujuh puluh tujuh rupiah), terdiri atas 5 (lima) sektor, yakni: Permukiman, Infrastruktur, Ekonomi, Sosial dan Lintas Sektor.

Tiga bencana yang secara bersamaan menimpa Sulawesi Tengah, gempa, tsunami, dan likuifaksi, mendorong munculnya kekacauan. Bencana yang melanda 27 September 2018 lalu di Sulawesi Tengah memang memunculkan suasana panik, dan kepanikan tersebut bukan hanya dirasakan masyarakat melainkan juga pemerintah daerah terdampak. Berbagai media menggambarkan kepanikan di tengah masyarakat, mulai air tanah merembes hingga pembakaran di rumah tahanan Donggala dan Palu yang mengakibatkan 1.425 warga binaan di rutan dan lapas keluar dari tahanan (Gabrillin dalam kompas.com, 1 Oktober 2018). Telekomunikan pun terbatas. Hanya satu provider telekomunikasi yang dapat aktif, itu pun hanya bisa diakses saat malam hari.

Menilik pengalaman-pengalaman sebelumnya dan berdasarkan katalog kejadian gempa bumi BMKG, masyarakat
Sulawesi Tengah sudah terbiasa dengan gempa. Terhitung sejak 1910 hingga 2017, wilayah Sulawesi Tengah paling tidak telah mengalami 130 kali kejadian gempa bumi yang bersifat merusak. Beberapa kejadian gempa bumi merusak tersebut pusat gempa buminya terletak di darat. Dalam catatan BMKG, empat bulan terakhir dari September 2018 telah terjadi gempa bumi di sejumlah wilayah di Sulawesi Tengah, 30 kali setiap hari, baik yang dirasakan maupun tidak dirasakan masyarakat.

Mengutip pernyataan Laksono Hari Wiwoho (dalam kompas.com, 23 Oktober 2018), sudah sejak 5 tahun lalu, Indeks Resiko Bencana Badan Nasional Penanggulangan Bencana untuk Donggala sudah masuk angka 189 atau tergolong tinggi. Di Kota Palu, indeks kerentanan seismik Kota Palu bahkan telah mencapai nilai yang sangat tinggi, bahkan tertinggi di antara kabupaten/kota lainnya di Sulawesi Tengah. Di Tahun 2012, Badan Geologi Kementerian ESDM melakukan penelitian terkait gejala alam likuifaksi di beberapa daerah. Hasil penelitian Badan Geologi Kementerian ESDM menyimpulkan Kota Palu menyimpan potensi likuifaksi dan diprediksi akan terjadi, mengingat pemicunya ada dan sangat aktif, yaitu sesar Palu Koro. Ancaman likuifaksi yang ditemukan di Kota Palu membuat Badan Geologi Kementerian ESDM merekomendasikan ke Pemerintah Kota Palu untuk mengatur tata ruang kota beraspek bencana. Dalam rekomendasi tersebut, pemerintah kota masih boleh mendirikan bangunan sepanjang memenuhi kaidah-kaidah tahan gempa, tidak membangun hunian tingkat tinggi, dan akan lebih baik bangunan berupa rumah kayu.

Sayangnya data ini diabaikan. Di tingkat yang lebih tinggi, yaitu Pemerintah Provinsi Sulawesi Tengah, isu manajemen bencana dan perubahan iklim belum sepenuhnya menjadi perhatian para stakeholder. Sekali lagi data tidak diindahkan. Padahal secara fakta, gempa yang acapkali melanda daerah Sulawesi Tengah sudah menjadi literasi alam betapa rawannya daerah ini. Ketika akhirnya 
bencana alam dengan skala besar terjadi pada September 2018, meski sudah pernah diprediksi, pemerintah provinsi Sulawesi Tengah dan pemerintah kabupaten-kota di Sulawesi Tengah yang terdampak bencana, karena belum pernah mendapatkan pengetahuan atau pengalaman menghadapi bencana sebesar itu, akhirnya mengalami kemacetan dalam bekerja. Trauma bencana yang dihadapi masyarakat membuat mereka belum bisa mengoordinasi dirinya dalam menghadapi musibah yang dihadapi. Terlebih pemerintah daerah terdampak bencana sempat lumpuh dan membiarkan alur koordinasi diambil alih pihak militer.

Kepanikan, trauma, koordinasi dan komunikasi terputus, dan lumpuhnya peran pemerintah daerah akhirnya memunculkan bencana sosial sehari setelah bencana alam, yaitu aksi penjarahan secara besarbesaran. Di Palu, kepanikan dan kekacauan di kalangan masyarakat sebagian berubah menjadi anarkis dengan terjadinya penjarahan oleh berbagai kelompok masyarakat yang tidak hanya terhadap toko-toko/outlet maupun gudanggudang yang mempunyai sediaan bahan kebutuhan pokok, tetapi juga meliputi barang-barang elektronik maupun sediaan barang-barang hasil bumi serta usaha franchise/waralaba dalam rentang waktu 29 September hingga 7 Oktober 2018.

Sebenarnya aksi penjarahan di Kota Palu bukanlah yang pertama. Penjarahan sebelumnya juga terjadi pascatsunami Aceh pada tahun 2004 dan pascagempa bumi di Padang. Pascatsunami di Aceh terjadi beberapa penerobosan toko kelontong yang rubuh, sementara di Padang pencurian dilakukan masyarakat di puing-puing reruntuhan ruko dan di beberapa titik lokasi. Namun penjarahan di kedua tempat tersebut tidak merebak luas seperti di Sulawesi Tengah. Menengok keluar Indonesia, 24 jam setelah terjadinya badai Harvey, otoritas keamanan Amerika Serikat berhasil mengamankan puluhan penjarah. Demikian juga dengan penjarahan pascabadai Katrina di New Orleans, Amerika Serikat 2005 lalu. Di tahun 2011, di Jepang, sekitar US\$5.8 juta dicuri dari ATM serta rumah dan toko dijarah pascagempa Tohoku berkekuatan 9 SR. Di Inggris 2015, penjarahan juga terjadi di rumah-rumah para korban banjir di Yorkshire. Di tahun yang sama, penjarahan besar-besaran juga terjadi di Cile pascabencana alam.

Pemaparan di atas memberikan gambaran bahwa penjarahan pascabencana terjadi sudah sejak lama, dan bukan hanya di Indonesia melainkan di berbagai belahan negara lainnya. Masalah sosial semacam ini bukannya tidak menjadi perhatian serius pemerintah. Penjarahan harta pascabencana telah diatur Perserikatan Bangsa-Bangsa (PBB) dalam Pinheiro Principles atau prinsip restitusi pemukiman dan property. Dalam prinsip tersebut ditegaskan bahwa negara harus mengambil langkah-langkah khusus untuk mencegah penghancuran atau penjarahan atas rumah sengketa atau ditinggalkan, tanah dan harta kekayaan.

Berdasarkan pemaparan di atas, tulisan ini mencoba untuk melihat lebih jauh penjarahan yang terjadi pascabencana alam di Kota Palu dari sudut pandang Pinheiro Principles dan pendekatan psikologi sosial.

\section{Rumusan Masalah}

Rumusan masalah dalam penelitian ini adalah:

1. Apa motif yang melatarbelakangi terjadinya penjarahan pascabencana alam pada 27 September 2018 di Kota Palu?

2. Bagaimana peran Pemerintah untuk mengatasi isu sosial pascabencana khususnya penjarahan yang terjadi pascabencana alam pada 27 September 2018 di Kota Palu?

\section{Tujuan dan Manfaat Penelitian}

Merunut dari rumusan masalah di atas, tujuan penelitian ini adalah untuk menganalisis motif penjarahan pascabencana alam pada 27 September 2018 di Kota Palu. Tujuan kedua adalah meninjau upaya-upaya yang telah dilakukan pemerintah dalam mengatasi munculnya isu sosial pascabencana khususnya penjarahan pascabencana di Kota Palu. 
Penelitian ini diharapkan memberikan manfaat bagi pengambil kebijakan terkait penanganan isu sosial sebagai bagian dari upaya menangani dampak buruk yang ditimbulkan oleh bencana. Selain dari itu, diharapkan penelitian ini memberikan ruang atau wadah bagi peneliti lainnya untuk ikut serta berkontribusi terhadap penanganan isu sosial yang ada di Indonesia.

\section{TINJAUAN PUSTAKA}

\section{Konsep Penjarahan}

Menurut Kamus Besar Bahasa Indonesia (KBBI) penjarahan berasal dari kata "jarah" yang berarti hasil rampasan. Sementara menjarah didefinisikan sebagai merebut dan merampas milik orang, terutama dalam perang atau dalam kekacauan. Penjarahan diartikan proses, cara, atau perbuatan menjarah. Dalam hukum pidana positif, penjarahan dikenal sebagai tindak pidana pencurian dengan pemberatan karena terdapat faktor yang memberatkan didaamnya, yaitu dilakukan pada saat keadaan peristiwa-peristiwa tertentu (Maghfiroh, 2019).

Penjarahan adalah suatu perbuatan tindak pidana yang dilakukan oleh seseorang atau berkelompok dengan mengambil barang yang bukan miliknya, dengan maksud untuk dimiliki sepenuhnya untuk dirinya sendiri dengan cara melawan hukum pada saat bencana alam. Dalam situasi pascabencana, masyarakat mengalami kepanikan, ketakutan dan kecemasan, serta kewaspadaan yang makin meningkat terhadap bahaya bencana yang mungkin akan terjadi lagi sehingga masyarakat tidak terlalu menghiraukan barang-barang yang telah ditinggalkannya. Keadaan tersebut memudahkan pelak untuk melakukan tindak kejahatan pencurian (Maghfiroh, 2019).

Pencurian dengan pemberatan diatur dalam Pasal 363 KUHP. Dalam pasal 363 terdapat unsur pemberatan, yaitu karena tindak pidana tersebut dilakukan oleh pelaku pada saat-saat tertentu, yaitu: (1) pada waktu terjadi kebakaran, (2) pada waktu terjadi ledakan, (3) pada waktu terjadi bahaya banjir, (4) pada wakt terjadi gempa bumi atau gempa laut, (5) pada waktu terjadi letusan gunung berapi, (6) pada waktu ada kapa karam, (7) pada waktu ada kapal terdampar, (8) pada waktu terjadi kecelakaan kereta api, (9) pada waktu terjadi suatu pemberontakan, (10) pada waktu terjadi huru hara, (11) pada waktu terjadi bahaya perang. Bilamana pencurian itu dilakukan dalam kondisi pada saat terjadinya berbagai macam malapetaka seperti yang dijelaskan di atas, pencurian ini diancaman hukuman lebih berat, karena pada waktu semacam itu orang-orang ribut dan barang-barang berharganya daam keadaan tidak terjaga (Soesilo, 1994 dalam Maghfiroh, 2019)

\section{Konsep Motif}

Motif adalah dorongan yang sudah terikat pada suatu tujuan. Motif menunjuk hubungan sistematik antara suatu respons atau suatu himpunan respons dengan keadaan dorongan tertentu. Apabila dorongan dasar itu bersifat bawaan, maka motif itu hasil proses belajar. Ada beberapa definisi tentang motif yang dikemukakan beberapa pakar (Ahmadi, 2007). Gerungan (1996) mendefinisikan motif sebagai suatu pengertian yang melengkapi semua pengerak alasan-alasan atau dorongan-dorongan dalam diri manusia yang menyebabkan ia berbuat sesuatu. Lindzey, Hall, dan Thompson (1975) menyatakan bahwa motif adalah sesuatu yang menimbulkan tingkah laku. Atkinson (1958) mendefinisikan motif sebagai suatu disposisi laten yang berusaha dengan kuat untuk menuju ke tujuan tertentu, tujuan ini dapat erupa prestasi, afiliasi, ataupun kekuasaan. Sri Mulyani Martaniah (1982) menyatakan bahwa motif adalah suatu konstruksi yang potensial dan laten, yang dibentuk oleh pengalaman-pengalaman yang secara relatif dapat bertahan meskipun kemungkinan berubah masih ada, dan berfungsi menggerakkan serta mengarahkan perilaku ke tujuan tertentu.

Gardner indzey, Calvin S. Hall, dan Richard F. Thompson dalam bukunya Psychology (1975 dalam Ahmadi, 2007) mengklasifikasikan motif menjadi dua, yaitu drives dan incentives. Drives yang 
mendorong seseorang untuk bertindak. Drives terbagi menjadi dua, drives primer atau drives yang tidak dipelajari. Contoh drives yang tidak dipelajari adalah lapar dan haus. Drives yang lain diperoleh melalui belajar, misalnya persaingan. Banyak motif yang melibatkan keduanya baik komponen yang dipelajari maupun yang tidak dipelajari. Incentives adalah benda atau situasi (keadaan) yang berada di dalam lingkungan sekitar kita yang merangsang tingkah laku. Incentives ini merupakan penyebab individu untuk bertindak.

\section{Manajemen Bencana}

Secara teori, manajemen bencana dimaknai sebagai sebuah disiplin untuk menangani dan mengatasi resiko, mempersiapkan diri sebelum bencana terjadi serta membangun kembali masyarakat setelah bencana alam terjadi (Feng, 2009 dalam Tantri, 2016). Sementara menurut United Nation International Strategy for Disaster Reduction (Tantri, 2016), manajemen bencana merupakan proses sistematik dalam menggunakan pedoman administratif, organisasi dan kemampuan operasional dan kapasitas dalam mengimplementasikan strategi-strategi, kebijakan, dan peningkatan kapasitas penanganan dalam mengurangi akibat yang merugikan atau mengalihkan kerusakan yang merugikan tersebut dengan aktivitas dan langkah pencegahan, mitigasi dan persiapan menghadapi bencana.

$$
\text { Meminjam pendapat Rijanta }
$$

(Rijantam dkk, 2018) manajemen bencana pada dasarnya terbagi menjadi empat kelompok besar; mitigasi, kesiapsiagaan, tanggap darurat, dan pemulihan. Dikaitkan dengan Undang-Undang Nomor 24 Tahun 2007, utamanya di Pasal 47 ayat 2, mitigasi adalah serangkaian upaya untuk mengurangi resiko bencana, baik melalui pembangunan fisik maupun penyadaran dan peningkatan kemampuan menghadapi ancaman bencana. Sementara kesiapsiagaan adalah serangkaian kegiatan yang dilakukan untuk mengantisipasi bencana melalui pengorganisasian serta melalui langkah yang tepat guna dan berdaya guna. Tanggap darurat bencana adalah serangkaian kegiatan yang dilakukan dengan segera pada saat kejadian bencana untuk menangani dampak buruk yang ditimbulkan, yang meliputi kegiatan penyelamatan dan evakuasi korban, harta benda, pemenuhan kebutuhan dasar, perlindungan, pengurusan pengungsi, penyelamatan, serta pemulihan prasarana dan sarana. Rehabilitasi adalah perbaikan dan pemulihan semua aspek pelayanan publik atau masyarakat sampai tingkat yang memadai pada wilayah pascabencana dengan sasaran utama untuk normalisasi atau berjalannya secara wajar semua aspek pemerintahan dan kehidupan masyarakat pada wilayah pascabencana.

\section{Pinheiro Principles}

Prinsip Pinheiro diambil dari hak dan regulasi yang diakui dalam hukum internasional yang mengikat dan telah disetujui oleh Sub Komisi Perserikatan Bangsa-Bangsa urusan Perlindungan dan Promosi Hak Asasi Manusia. Prinsip Pinheiro menjadi standar normatif bagi penegakan hak penduduk korban bencana alam (Harper, 2009).

Prinsip Pinheiro menyatakan bahwa negara harus mengambil langkah-langkah khusus untuk mencegah penghancuran atau penjarahan, yang salah satunya adalah harta kekayaan. Untuk itu hal-hal yang dapat ditempuh antara lain:

1. Untuk meminimalkan pengrusakan atau penjarahan, negara harus mengembangkan prosedur untuk menginventarisir isi dari rumah, tanah, serta harta kekayaan yang diadukan dalam konteks program restitusi rumah, tanah, dan harta kekayaan. Faktor yang menyulitkan adalah bahwa kerusakan fisik yang luas ditambah dengan kemampuan penegakan hukum dan ketertiban yang lemah sering menyulitkan polisi mengumpulkan bukti-bukti atau melakukan investigasi. Dalam situasi demikian, penghuni harus didorong untuk menemukan bukti penjarahan serta membuat inventaris terhadap barang sebelum evakuasi atau 
sesegera mungkin setelah mereka sampai di tempat penampungan darurat. Dokumen tersebut dapat berguna jika kebijakan restitusi dilaksanakan, jika tindakan hukum diambil terhadap persangka penjarahan, atau ketika mengajukan tuntutan dalam polis asuransi pribadi (Harper, .

2. Pejabat yang berwenang harus diminta untuk melindungi, sedapat mungkin, terhadap penjarahan, pengrusakan, serta penguasaan secara sewenangwenang dan ilegal, penempatan atau pemanfaatan harta atau hak milik orang-orang atau komunitas yang terdampak bencana

3. Konsultasi adalah sarana untuk menampung harapan dan menjamin bahwa setiap proses yang dikembangkan adalah adil dan dapat diterima oleh penduduk. Bila harapan tidak dipenuhi maka penjelasan dan umpan balik harus disediakan untuk mengurangi kekecewaan dan penolakan di kemudian hari.

\section{METODOLOGI PENELITIAN}

Penelitian dilaksanakan dengan menggunakan metode kualitatif deskriptif. Data yang digunakan dalam penelitian ini adalah data primer dan data sekunder. Data primer dilakukan melalui Focus Group Discussion dan wawancara mendalam dengan beberapa key informant manajemen kebencanaan, antara lain dengan pejabat struktural dari BPBD Kota Palu dan Provinsi Sulawesi Tengah, Bappeda Kota Palu, Korem 132/Tadulako, dan Polres Kota Palu. Data sekunder yang dikumpulkan berupa dokumen-dokumen kebencanaan Kota Palu, seperti Laporan Analisis Indeks Kerentanan Seismik Kota Palu, Dokumen Rencana Penanggulangan Bencana Kota Palu, RPJMD, dan beberapa dokumen lainnya.

Potret penjarahan dianalisis melalui pendekatan psikologi sosial, sementara peran pemerintah dalam mengatasi penjarahan ditinjau berdasarkan Pinheiro Principles pada masa tanggap darurat.
Potret dan peran pemerintah dianalisa secara kualitatif dan dideskripsikan dengan langkah-langkah yang digambarkan oleh Miles and Huberman (dalam Sugiyono, 2010). Langkah-langkahnya terdiri dari data collection, data reduction, data display, dan conclusions (drawing/ verifying).

\section{HASIL DAN PEMBAHASAN PENELITIAN}

\section{Hasil Penelitian}

Hasil penelitian didasarkan pada dua hal sesuai dengan tujuan penelitian, yaitu motif penjarahan pascabencana alam pada rentang waktu 29 September hingga 7 Oktober 2018 di Kota Palu, dan meninjau upaya-upaya yang telah dilakukan pemerintah dalam mengatasi penjarahan pascabencana di Kota Palu.

\section{Motif Penjarahan Pascabencana Alam di Kota Palu}

Pascabencana alam di Kota Palu penjarahan terjadi di berbagai supermarket (BNS Smart, Alfa Midi, Grans Mall dan Mall Tatura/Ramayana) dan penjarahan bahan bakar minyak (BBM) di beberapa stasiun pengisian bahan bakar umum. Bukan hanya kebutuhan pokok berupa makanan atau bahan makanan yang menjadi jarahan, penjarahan bahkan sampai pada kebutuhan lain, termasuk barang-barang elektronik, perhiasan emas, maupun ATM. Di Kota Palu, paling tidak 40 swalayan sedang dan 1 gerai swalayan kecil menjadi sasaran penjarahan massa. Masyarakat yang tidak menjarah memilih melakukan perampasan terhadap kiriman bantuan makanan (Syah, 2019).

Beragam latar belakang yang dirangkum dan menjadi penyebab munculnya penjarahan dapat dipetakan sebagai berikut:

1. Schulze, dkk (dalam Samad) mengungkapkan bahwa kondisi umum tentang perilaku masyarakat dalam situasi bencana seringkali tidak lagi berdasar pada data empiris, tetapi lebih kepada insting untuk mempertahankan diri terhadap situasi. Penjarahan salah satu pilihan agar 
dapat tetap bertahan hidup. Hal ini didukung pula oleh pernyataan pakar psikologi sosial dari Universitas Indonesia, Endang Mariani, yang menjelaskan bahwa pada umumnya penjarahan terkait dengan upaya untuk mempertahankan hidup. Menurutnya, mengambil bahan kebutuhan pokok dari toko atau gudang, masih tergolong sebagai upaya untuk mempertahankan diri dan lebih didorong pada kebutuhan bertahan hidup. "Dalam situasi pasca bencana masyarakat biasanya mengalami kepanikan, ada ketakutan dan kecemasan yang meningkat, apalagi dalam kondisi ketidakpastian cukup panjang," (dalam bbc.com, 2 Oktober 2018). Pernyataan yang sama dilontarkan Purniati, pakar kriminologi dari Universitas Indonesia, yang menyatakan bahwa kondisi bencana alam memang mendorong kepanikan masyarakat, terutama terkait hal-hal dasar untuk bertahan hidup. Kepala Kantor Komisi Nasional Hak Asasi Manusia (Komnas HAM) Sulawesi Tengah (dalam voaindonesia.com, 1 November 2018) menyatakan bahwa korban yang lapar menjarah toko-toko, awalnya karena mencari bahan makanan. Penjarahan yang awalnya untuk memenuhi kebutuhan pokok kemudian lepas kendali dan tidak lagi sebatas ke kebutuhan pokok namun telah mengarah ke kebutuhan sandang dan papan.

2. Timbulnya loss government. Pemerintah kota Palu tidak berdaya dalam memberikan regulasi yang tepat pasca bencana sehingga masyarakat melihat terjadinya loss government dan peluang tersebut dimanfaatkan beberapa kelompok oknum masyarakat untuk melakukan tindakan penjarahan dengan eskalasi bencana yang terbilang cukup luas dan besar. Kesimpulan di atas didukung oleh Adrianus, Kriminolog Universitas Indonesia, (Agung, dalam https:// uzone.id, 4 Oktober 2018) yang menyatakan bahwa situasi di lokasi bencana dapat memicu kondisi lawless di mana norma hukum yang berlaku menjadi abu-abu. Sebagian dianggap karena minimnya personel keamanan yang berjaga di lokasi bencana. Hal ini diperparah pula dengan reaksi yang tidak cukup cepat dari aparat untuk mengantisipasi terjadinya lawless yang akhirnya berujung pada penjarahan di Palu.

Kondisi di atas didukung oleh pernyataan Kepala Kantor Komisi Nasional Hak Asasi Manusia (Komnas HAM) Sulawesi Tengah (dalam voaindonesia.com, November 2018). Menurutnya,

"Dalam tiga hari pertama bencana negara tidak hadir di tengah korban. Ketidakhadiran negara ini terlihat dari tidak adanya peran menonjol pemerintah daerah, termasuk badan-badan yang seharusnya berperan langsung, seperti Kementerian Sosial.... Situasi itu diperparah oleh ketidakhadiran aparat keamanan. Ada aparat satu dua orang atauu satuu regu, tetapi cenderung membiarkan hal itu."

Penjarahan yang terjadi di berbagai toko dan gudang baik itu kebutuhan pokok, barang elektronik, dan hasil bumi semakin meluas dan tidak terkendali akibat ketidaksiapan dan ketidaksigapan pemerintah baik di pusat maupun di daerah serta aparat keamanan dalam melakukan langkahlangkah pencegahan dan pemulihan untuk menstabilkan kekacauan sosial dan keamanan pascabencana dalam rentang waktu 29 September hingga 7 Oktober 2018. Kompas TV tanggal 30 September 2018 menyiarkan pernyataan Menteri Dalam Negeri yang pada pokoknya menyebutkan bahwa,"sementara menunggu bantuan yang akan tiba, masyarakat dapat memanfaatkan stok makanan yang tersedia di toko-toko di lokasi gempa. Nantinya pembayaran akan dilakukan Pemerintah". Pernyataan ini kemudian terkonfirmasi melalui 
pernyataan Menkopulhukam dalam statement yang disiarkan secara nasional oleh TV Inews tanggal 30 September 2018 yang pada pokoknya menyatakan bahwa, "memang ada suatu kebijakan yang membolehkan mereka "ngambil (red. mengambil) tetapi akan dibayar oleh pemerintah untuk memudahkan mereka mendapatkan distribusi makanan cepat saji". (Putusan Perdata Gugatan Nomor 21/Pdt.G/2019/PN Pal).

Namun pernyataan di atas kemudian dibantah oleh Menteri Dalam Negeri dan Menkopulhukam yang menyatakan bahwa tidak ada pernyataan keduanya yang mempersilahkan warga masyarakat secara bebas untuk mengambil barang pada toko, warung dan minimarket tanpa membayar, serta tidak ada jaminan bahwa Pemerintah yang akan membayar. Menteri Dalam Negeri hanya menyampaikan yang pada intinya memperkenankan warga untuk mengambil di alfamart serta toko kelontong dengan pengawalan pihak kepolisian dan mendata barangbarang yang diambil untuk kemudian dibayar oleh Pemerintah. Toko-toko yang dimaksud adalah yang dapat memfasilitasi kebutuhan bahan pokok, seperti sembako, mie instant, air minum, dan bahan bakar dalam rangka memenuhi kebutuhan masyarakat yang tertimpa bencana gempa Palu. Selanjutnya barangbarang yang diberikan kepada masyarakat tersebut didata dan diinventarisir untuk dapat dibayarkan Pemerintah sebagai salah satu bagian dari upaya tanggap darurat Palu. Menurutnya, jika pengambilan barang dilakukan tanpa pengawalan dari pihak kepolisian serta tidak terinventarisirnya barang-barang yang diambil maka hal tersebut di luar kewenangan Pemerintah dan murni merupakan kasus penjarahan. (Putusan Perdata Gugatan Nomor 21/ Pdt.G/2019/PN Pal)

3. Sosiolog Rissalwan Habdy Lubis (dalam Fadel Prayoga, www.okezone.com, 3 Oktober 2018) mencatat ada empat penyebab utama mereka melakukan aksi penjarahan di Kota Palu, diantaranya faktor agama, adat, lingkungan, dan pemberitaan di media. Dari dimensi dan adat, nampaknya penduduk di sana sangat lemah dalam menjunjung norma agama ketika menjalani kehidupan sehari-hari. Alhasil, moral di dalam dirinya merasa kalau menjarah itu merupakan perbuatan yang benar. Lalu, dilihat dari faktor lingkungan, Rissalwan menilai ada keteledoran dari aparat kepolisian untuk mencegah aksi penjarahan. Dari sisi dimensi alam dan lingkungan, peran solidarias sosial dan juga aparat keamanan menjadi kunci untuk bisa mencegah terpicunya kekacauan pascabencana. Tak hanya itu, adanya artikel media online yang menuliskan pemerintah mengizinkan masyarakat untuk mengambil barang-barang yang ada di toko karena nantinya kebutuhan pokok yang diambil akan dibayarkan pemerintah menjadi pemicu mereka untuk semakin brutal melakukan penjarahan di jalanan. Dimensi artikuasi media ini menjadi puncak legalisasi perilaku brutal tersebut.

Senada dengan temuan Rissalwan di atas, Ketua Umum Lembaga Perlindungan Anak, Seto Mulyadi, mengungkapkan bahwa hasil temuan salah satu riset menyimpulkan kondisi sosial ekonomi menjelang bencana berhubungan dengan perilaku penjarahan setelah bencana. Semakin buruk kondisi sosial ekonomi setempat sesaat sebelum bencana datang, semakin tinggi pula tingkat penjarahan di situ (Mulyadi, https://www.beritasatu.com, Oktober 2018).

4. Kekerasan yang menjalar dan deindividuation. Dalam masyarakat selalu ada orang yang berniat buruk, tapi dalam kerumunan, niat buruk ini bisa menular dengan cepat. Kerumunan massa membuat orang merasa anonim sehingga kehilangan rasa tanggung jawab, dan mudah ikut- 
ikutan. Massa yang berkumpul bisa meningkatkan perilaku instingtif, yakni ketika seseorang bertindak tanpa pikir panjang. Warga bisa lebih mudah melakukan hal-hal yang sebenarnya tidak akan dilakukannya dalam kondisi biasa. Orang yang berada dalam kelompok akan melakukan sesuatu yang tidak akan mereka lakukan bila mereka seorang diri.

\section{Upaya yang telah Dilakukan Pemerintah untuk Mengatasi Isu Sosial Pascabencana, Khususnya Penjarahan Pascabencana Alam}

Tanggung jawab pemerintah daerah berdasarkan UU Nomor 24 tahun 2007 tentang Penanggulangan Bencana dalam kaitannya dengan kasus penjarahan yang terjadi ada dua: pertama, penjaminan pemenuhan hak masyarakat, dan kedua, perlindungan masyarakat. Disandingkan dengan Pinheiro Principles, Pinheiro Principles menyebutkan bahwa negara harus mengambil langkah-langkah khusus untuk mencegah penghancuran atau penjarahan atas rumah sengketa atau ditinggalkan, tanah dan harta kekayaan. Terkait dengan hal tersebut langkahlangkah khusus yang diambil negara dalam penelitian ini mengacu pada peran pemerintah pusat dan pemerintah daerah dalam upaya mengatasi penjarahan pascabencana alam.

Pemerintah Pusat. Presiden memerintahkan Kepala Kepolisian Republik Indonesia (Kapolri) dan Panglima Tentara Nasional untuk membagi personil yang ada selain melakukan operasi pencarian dan evakuasi korban juga menjaga titik-titik pusat ekonomi dan Stasiun Pengisi Bahan Bakar (SPBU) sehingga masyarakat tertib, para pemilik toko dapat membuka usahanya kembali, dan aktivitas ekonomi kembali normal. Di samping itu, dalam rapat terbatas tanggal 2 Oktober 2018 pukul 10.45 WIB Presiden memerintahkan Kapolri untuk segera melakukan penegakan hukum terkait perbuatan pidana berupa pencurian dan penjarahan yang terjadi di Kota Palu (Putusan Perdata Gugatan Nomor 21/Pdt.G/2019/PN Pal).
Di samping itu, penambahan personel dari berbagai wilayah ke Kota Palu juga dilakukan mengingat cukup banyak personel kepolisian dan TNI di Kota Palu dan kepolisian daerah Sulawesi Tengah turut menjadi korban.

Menteri Koordinator Bidang Politik Hukum dan Keamanan bersama-sama dengan Panglima TNI, Menteri Dalam Negeri, Menteri Sosial, Menteri Perhubungan, Wakil Kapori, Deputi V dan Staf Ahli Kementerian Koordinator Bidang Politik Hukum dan Keamanan, serta unsur Pemerintah Daerah Sulawesi Tengah dan Kota Palu melakukan rapat darurat yang dipimpin oleh Menteri Koordinator Bidang Politik Hukum dan Keamanan. Hasil rapat memutuskan bahwa toko-toko kelontong yang masih mempunyai persediaan makanan dan minuman dianjurkan untuk buka dan melayani masyarakat, dan agar prosesnya berjalan tertib diputuskan bahwa masyarakat yang akan mengantri mengambil kebutuhan makanan akan didampingi oleh petugas dan bahan makanan yang diambil diinventarisir kemudian langsung dibayar oleh pemerintah pada saat itu juga menggunakan uang yang terkumpul dari Menteri Koordinator Bidang Politik Hukum dan Keamanan. Uang yang terkumpul tersebut berasal dari seluruh peserta rapat darurat. Keputusan yang diambil sebagai bentuk tanggung jawab dan sebagai langkah paling cepat yang bisa dilakukan oleh pemerintah.

Menteri Dalam Negeri pada tanggal 1 Oktober 2018, bertempat di kantor Kementerian Dalam Negeri, melakukan konferensi pers dan memberikan penjelasan secara panjang lebar terkait upaya dan langkah-langkah yang telah diambil Pemerintah. Diantara penjelasannya tersebut, Menteri Dalam Negeri menyatakan sebagai berikut:

“... Akhirnya saya dan Pak

Willian memutuskan dengan Pak

Gubernur didampingi polisi, alfamart-alfamart itu tolong dibuka, dijaga, diinventarisir ngambil apa-ngambil apa, nanti 
dibayar. Pak William juga bawa uang, saya juga bawa uang, Pemda juga usah siap Pak Gubernur. Pokoknya toko-toko kelontong yang jual air minum, jual supermi, ambil dulu aja..." (Putusan Perdata Gugatan Nomor 21/Pdt.G/2019/ PN Pal).

Di tanggal yang sama namun di tempat yang berbeda, bertempat di Kementerian Koordinator Bidang Politik Hukum dan Keamanan, Menteri Koordinator Bidang Politik Hukum dan Keamanan menyampaikan kebijakan yang diambil terkait kekurangan bahan makanan di Kota Palu. Penjelasannya dalam konferensi pers sebagai berikut:

“.... Karena keterbatasan supply makanan dan minuman yang kemudian berangsurangsur habis ya, maka mereka tentu akan mengambil barangbarang di toko-toko makanan dan minuman itu ya, mini-mini market itu. Tapi pada saat kemarin kita rapat, kita bijaksanakan bahwa ada Mendagri, ada BNPB, ada Gubernur, ada saya, ada Kapolda, ada Pangdam, Panglima TNI, maka kemudian kita bijaksanakan bahwa lebih baik daripada penjarahanpenjarahan liar, lebih baik kita buka saja mini-mini market itu diambil barangnya, diganti nanti dengan uang ya...".

Pernyataan di atas dikeluarkan sebagai jawaban atas pertanyaan yang diajukan wartawan, bukan pengumuman yang berisi kebijakan yang diambil Pemerintah (Putusan Perdata Gugatan Nomor 21/ Pdt.G/2019/PN Pal).

\section{Kepolisian Daerah Sulawesi} Tengah. Pascabencana alam, pengecekan terakhir jumlah personil yang dilakukan mendapatkan hasil bahwa kekuatan personil yang dapat dipergunakan saat itu berkurang tinggal 30 persen saja. Selebihnya tidak mampu bertugas karena mereka dan keluarganya turut menjadi korban dalam peristiwa tersebut. Anggota Polri Polda Sulteng yang berdomisili di Kota Palu, Sigi, Donggala, dan Parimo turut menjadi korban dengan rincian 19 meninggal dan 150 luka berat dan ringan.

Dalam wawancara yang dilakukan, narasumber dari Polres Kota Palu menyatakan bahwa kepolisian bekerja berdasarkan aturan yang ruang lingkupnya adalah mengayomi, membimbing, melindungi, dan menegakkan hukum. Pada saat bencana, kepolisian menggunakan pendekatan preemtif, yaitu dengan cara menyampaikan kepada masyarakat agar tidak perlu takut karena bencana yang sifatnya besar hanya satu kali, selebihnya adalah relatif lebih kecil. Hal ini disampaikan karena pada saat bencana, TNI Polri yang selalu siap di lapangan sehingga sering menjadi sasaran pertanyaan masyarakat yang khawatir akan bencana selanjutnya. Pendekatan preemtif dilakukan dalam bentuk membimbing dan memberikan penyuluhan kepada masyarakat agar jangan terlalu panik.

Selain preemtif, TNI Polri juga melakukan tindakan preventif, yaitu menegaskan kepada masyarakat untuk tidak memanfaatkan kesempatan dengan mengambil barang milik orang lain. "Tolong seluruh masyarakat, jangan mengambil barang-barang milik orang lain" (Hasil wawancara tanggal 19 Juni 2019). Menurutnya, pada saat kepanikan terjadi, banyak warga membongkar ATM, pertokoan dijarah. Di awal terjadinya penjarahan, belum ada tindakan yang dilakukan kepolisian. Hal ini disampaikan oleh Kepala Seksi Pencegahan dan Kesiapsiagaan BPBD Kota Palu yang menyatakan bahwa pada awal penjarahan di beberapa tempat pihak kepolisian hanya melakukan pengawasan terhadap lokasi yang dijarah karena belum ada insruksi lebih lanjut. Hal yang sama dilakukan di lokasi ATM, "pendekatan yang dilakukan oleh polisi mereka tidak melarang tetapi memfoto orang itu (red. narapidana), kemudian akan dicari (red. setelah berkoordinasi dengan pihak Lapas)". 
Namun, lanjutnya, di tempat lainnya, aparat TNI yang menangkap pelaku penjarahan langsung memberikan sanksi di tempat, "didapat tentara, disuruh berdiri disitu disuruh telanjang pakai cawat mami dicambuk pake selang. Pokoknya dikasi tobatlah" (Hasil wawancara tanggal 19 Juni 2019). Setelah ada instruksi, pihak kepolisian akhirnya melakukan tindakan represif, yaitu menangkap siapa pun yang kedapatan melakukan penjarahan. "Kami sudah berupaya.... Itu sudah kami proses dan bawa ke pengadilan" (Hasil wawancara tanggal 19 Juni 2019).

Hal yang sama dikemukakan Danramil Sirenja bahwa semua wilayah termasuk koramil-koramil yang berada di wilayah terpencil langsung melakukan aksi. TNI-Polri bersama-sama mengamankan wilayah jangan sampai ada masyarakat yang memanfaatkan situasi. "Selain itu kita juga melaksanakan pengamanan dibantu bapak kepolisian mengamankan wilayah. Jangan sampai ada masyarakat yang memanfaatkan situasi, orang-orang pada lari, dia bersenang-senang di atas penderitaan orang lain" (Hasil wawancara tanggal 19 Juni 2019). Polri bersama-sama dengan TNI mengamankan depo BBM, jalur distribusi logistik, stasiun pengisian bahan bakar, dan gudang-gudang termask gudang Bulog.

Tanggal 27 September 2018, Kapolda Sulawesi Tengah, setelah memetakan situasi dan kekuatan personil yang dimiliki, segera memerintahkan kepada para Kapolres di wilayah Pasigala untuk melakukan langkah penanganan wilayah tugas masing-masing sesuai SOP. Pasukan pendukung Dit.Sabhara Polda Sulteng diperintahkan untuk masuk ke dalam Kota Palu dengan tugas utama pertolongan jiwa. 143 petugas menempati menempati Pos Aju Perintis di sekitar Swalayan Carrefour dekat Kantor BNI Palu. Penempatan Pos Aju di dekat lokasi Carrefour atas dasar pertimbangan taktis karena strategis guna pengamanan di dalam wilayah Kota Palu.

$$
\text { Kapolda Sulawesi Tengah }
$$

memerintahkan tim khusus yang semula telah dibentuk untuk melakukan penegakan hukum untuk melakukan penangkapan terhadap pelaku pencurian serta melakukan proses hukum sesuai ketentuan yang berlaku. Sesuai dengan KUHP di Pasal 363, ancaman pidana pencurian pada saat bencana alam lebih berat dibandingkan dalam kondisi normal. Tim penegakan hukum yang bertugas pascabencana alam terdiri dari personil Polres Palu sebanyak 27 orang, tim personil Direskrimum Polda Sulteng berjumlah 18 orang, tim pencegahan Dit.Sabhara sebanyak 20 orang, dan Brimob 20 orang. Upaya penegakan hukum menghasilkan sebagai berikut (Putusan Perdata Gugatan Nomor 21/ Pdt.G/2019/PN Pal):

a. Polres Palu melakukan penangkapan dan pengamanan sebanyak 502 orang di berbagai tempat di Kota Palu. Sebanyak 364 orang dikembalikan karena tidak cukup bukti. 138 orang ditetapkan sebagai tersangka yang selanjutnya dilakukan penahanan.

b. Tim Direskrimum Polda Sulteng melakukan penangkapan terhadap 24 orang. Sebanyak 16 orang dikembalikan karena tidak cukup bukti dan 8 orang ditetapkan sebagai tersangka. Tindak pidana pencurian hampir menyebar di seluruh Kota Palu dalam waktu yang hampir bersamaan. Hal ini menyebabkan tidak seluruhnya dapat dilakukan penindakan. Penindakan yang dapat dilakukan hanyalah sebagian kecil saja karena keterbatasan jumlah personil

c. Upaya penjarahan yang tidak dapat dicegah disebabkan faktor tidak berdayanya anggota Polri menghalangi akibat banyaknya massa yang datang untuk melakukan penjarahan. Upaya yang dilakukan hanya memberikan tembakan peringatan dan melaporkan situasi yang dihadapi kepada atasan.

d. Masyarakat yang melakukan penjarahan setelah gempa bumi terjadi di Kota Palu, Kabupaten Sigi dan Kabupaten Donggala dalam periode tanggal 29 September hingga 7 Oktober 2018 telah dilakukan penegakan hukum oleh Kepolisian 
Resort Kota Palu dan telah disidangkan di Pengadilan Negeri Palu dan telah diputus dengan putusan pengadilan yang telah berkekuatan hukum tetap.

Selain yang telah dilakukan diatas, Polresta Palu juga menyita berbagai jenis barang bukti hasil penjarahan. Di samping itu polisi juga terus melakukan patroli di seluruh wilayah Kota Palu dalam rangka mengantisipasi dan mengejar para pelaku penjarahan pascabencana.

\section{Pemerintah Daerah.}

Pascabencana alam, Gubernur Sulawesi Tengah terus memastikan agar seluruh Satuan Tugas tetap melakukan upaya pengamanan. Pengawalan dari aparat dilakukan pada semua bantuan yang melalui jalur darat guna mencegah terjadinya penjarahan di beberapa titik rawan. Hal lain yang dilakukan adalah terus menerus berkoordinasi dengan institusi kepolisian.

Kepala Seksi Pencegahan dan Kesiapsiagaan BPBD Kota Palu dalam wawancara mengiyakan bahwa memang pada saat terjadi bencana alam, terjadi pula penjarahan di Kota Palu. "itu memang sudah menjurus krimimal... Saya saya tidak bohong jujur saja kriminal di Kota Palu sudah mulai... banyak toko toko besar swalayan yang ikut dijarah.... banyak toko toko besar swalayan yang ikut dijarah". Bahkan, menurut Sekretaris BPBD Kota Palu mereka pun kena jarahan, "Kami mengurus beras bulog. Saya diperintahkan oleh Wakil Walikota untuk mengambil beras itu. Setelah itu kami pakai kendaraan untuk ke lokasi sasaran bencana tapi banyak beras yang dijarah oleh masyarakat" (Hasil wawancara tanggal 19 Juni 2019). BPBD Kota Palu tidak mengambil tindakan apa pun terhadap tindakan penjarahan karena hal tersebut bukan ranah kewenangan mereka.

Pascabencana, pemerintah daerah Kota Palu mengalami masalah logistik. Kelambatan tersebut, menurut Kepala Bappeda akibat lambatnya peran Kementerian Sosial dalam menyalurkan bantuan logistik. "Akibatnya kita di daerah ini mengalami persoalan terkait logistik...Di saat tanggap darurat Pemerintah Kota Palu hanya mengharapkan bantuan logistik dari luar negeri dan dalam negeri. Bantuan logistik itu yang kami distribusi ke 412 titik pertama" (Hasil wawancara tanggal 19 Juni 2019). Menurutnya, kondisi darurat inilah yang mengganggu kondisi ketertiban dan keamanan.

Sesuai dengan Pinheiro Principles, pada masa pemulihan, BPBD Sulawesi Tengah dan Kota Palu menginventarisir kerugian akibat penjarahan. Kerugian ini dimasukkan dalam lima sektor kerugian daerah, termasuk di dalamnya sektor pertanian dan perdagangan. Hingga akhir tahun 2019 masalah ganti rugi penjarahan belum dikoordinasikan lebih lanjut. Pemerintah Kota Palu masih fokus pada pembangunan rumah tinggal. Selain itu BPBD juga menginventarisir rumah dan tanah masyarakat yang terdampak bencana. Inventarisir ini dilakukan untuk perbaikan lingkungan daerah bencana, pemberian bantuan perbaikan rumah, dan pembangunan kembali sarana sosial masyarakat. Upaya tersebut dilakukan pada tahap pemulihan.

\section{PEMBAHASAN}

Penjarahan yang terjadi pascabencana di Kota Palu, menurut sudut pandang Wesley Hohfed dan Hart (dalam Held, 1991) tidak lain merupakan implementasi dari hak mencoba melakukan atau memiliki sesuatu atau memperoleh apa yang masyarakat butuhkan untuk hidup. Kebutuhan (dalam Ahmadi, 2007) dapat dipandang sebagai kekurangan adanya sesuatu, dan ini menuntut segera pemenuhannya agar segera mendapatkan keseimbangan. Situasi kekurangan ini berfungsi sebagai suatu kekuatan atau dorongan alasan yang menyebabkan seseorang bertindak untuk memenuhi kebutuhan.

Secara etika, penjarahan barangbarang pascabencana di Palu mungkin sulit diterima. Perilaku ini mungkin menjadi jelas bila kita memahami aksi penjarahan ini sebagai akibat dari proses pembenaman identitas individual 
demi

kepentingan

kelompok atau deindividuation yang ekstrem, di saat warga membangun modal sosial menghadapi bencana. Menurut teori deindividuation, perilaku seorang individu ketika sedang sendiri cenderung berbeda ketika individu itu sedang berinteraksi dalam kelompok (theconversation.com, 3 Januari 2019). Dalam situasi kebersamaan (togetherness situation), adanya orang lain di luar dirinya mempengaruhi tingkah laku seseorang. Orang tidak mau terlalu berbeda jauh dengan orang-orang di sekitarnya (Ahmadi, 2007). Di dalam kelompok, nilai dan prinsip-prinsip individu cenderung ditekan agar modal sosial dapat tumbuh. Dalam situasi kritis seperti bencana, prinsip-prinsip moral individu yang awalnya kuat dibenamkan dan diganti dengan norma bersama yang muncul sebagai modal untuk menyelesaikan persoalan yang mendesak. Norma kelompok itu muncul melalui proses saling bertukar informasi.

Kondisi diatas didukung oleh pernyataan LeBon yang berpendapat bahwa bila seorang individu itu berada dalam ikatan massa (crowd) maka ia akan merasa, berpikir, dan bertingkah laku yang berbeda apabila individu itu dalam keadaan sendirian terpisah dari orang lain (Ahmadi, 2007). Dalam tulisan yang lain, LeBon (1896 dalam Sears, 1992) mengamati bahwa orang yang berada dalam kerumunan sering merasa bebas untuk memuaskan nalurinya yang "liar dan destruktif". Tindakan di atas merupakan salah satu bentuk agresi imitatif dalam bentuk kekerasan yang menjalar (contagious violence). Sosiolog Perancis, Tarde, dan Berkowitz (dalam Sears, dkk, 1992) mengungkapkan beberapa bukti tindak pidana yang mengilhami terjadinya kejahatan yang serupa. Dengan demikian sebuah kerumunan dapat berpotensi melahirkan kekerasan yang menjalar akibat perilaku yang tidak terkendali. LeBon berpendapat bahwa alasannya terletak pada dua karakteristik orang yang berada dalam kerumunan besar: tidak terkalahkan dan anonimitas. Menurutnya, individu yang menjadi bagian kerumunan memperoleh perasaan tidak terkalahkan yang memungkinkan dia memunculkan nalurinya. Selain itu, suatu kerumunan menjadi anonim, dan akibatnya menjadi tidak bertanggung jawab, rasa tanggung jawab yang selalu mengendalikan individu hilang sama sekali. Orang merasa bahwa kelompok lah yang bertanggung jawab sehingga mereka tidak dapat dikenakan hukuman secara pribadi melainkan kelompok. Identitas pribadi digantikan oleh suatu identitas dengan tujuan dan tindakan kelompok.

Penjarahan yang terjadi di Kota Palu merebak akibat mekanisme kendali seseorang melemah sehingga dorongandorongan primitif dan agresif menjadi bebas diungkapkan, dan ini menyebabkan timbulnya kekerasan dan tindakan tidak bermoral. Dalam bukunya Going to Extremes، (2009) pakar hukum dan ekonomi Universitas Harvard, Cass Sunstein, (dalam Daniel, 2019), menyatakan bahwa ketika individuindividu yang sedang menghadapi persoalan bersama saling bertukar informasi sebagai sebuah kelompok, mereka cenderung akan menghasilkan sikap dan tindakan yang lebih ekstrem dibanding sikap dan tindakan mereka sebagai individu. Pernyataan tersebut senada dengan LeBon. Ketika warga bertukar informasi dan menyadari bahwa mereka sedang berada dalam krisis, norma "apa saja baik dilakukan agar bisa keluar dari krisis" mudah muncul dan dibenarkan. Apabila seorang warga melihat warga lain mengambil barang tertentu yang sesungguhnya bukan kebutuhan pokok, maka ia pun mudah membenarkan bahkan meniru perilaku tersebut, karena norma kelompok yang terbentuk telah membenamkan prinsip moral yang dipegangnya. Dalam kasus ini, penjarahan dilakukan karena ada yang mendahului sehingga yang lain kemudian mengikuti. Tindakan ini juga didukung oleh adanya pemberitaan yang meluas terkait izin pemerintah untuk mengambil barang dagangan sehingga yang terjadi adalah perbuatan massa yang tak terkendali.

Perbuatan massa yang tidak terkendali 
menrut Adrianus, Kriminolog Universitas Indonesia, (Agung, dalam https://uzone.id, 4 Oktober 2018) dapat memicu kondisi lawless di mana norma hukum yang berlaku menjadi abu-abu. Sebagaimana dikemukakan dalam pasal 84 KUHP orang yang melakukan tindak pidana karena pengaruh daya paksa tidak dapat dipidana. Keadaan darurat masuk dalam rumpun daya paksa sebagaimana yang diatur dalam pasal 48 KUHP tersebut. Hal ini masuk dalam prinsip hukum pidana nessitasnon hebetlegen (dalam keadaan darurat tidak berlaku hukum), nessitas facit licitum quod (keadaan terpaksa membolehkan apa yang dilarang). Dengan kata lain kondisi di atas dalam situasi tertentu dapat masuk dalam hukum kedaruratan dan tidak masuk dalam kategori pelanggaran hukum.

Ditinjau dari motif, sebagaimana pemaparan Gardner indzey, Calvin S. Hall, dan Richard F. Thompson dalam bukunya Psychology (1975 dalam Ahmadi, 2007), motif yang mendasari perilaku penjarahan secara umum terbagi atas dua, yaitu drives dan incentives. Drives dipicu oleh kebutuhan masyarakat untuk memenuhi kebutuhan dasarnya, yaitu pemenuhan kebutuhan pangan. Lapar menyebabkan masyarakat bertindak untuk mendapatkan makanan. Sementara incentives adalah lingkungan yang mendukung dan menggerakkan seseorang untuk bertindak meski tanpa adanya drives. Dalam kasus di Palu, penjarahan terjadi karena kedua hal tersebut; masyarakat melakukan penjarahan untuk memenuhi kebutuhan pangannya, sementara incentives muncul akibat lingkungan yang mendukung, yaitu lemahnya pengawasan aparat, kondisi kacau balau, kondisi toko bahan pangan dan toko-toko lainnya dalam kondisi terbuka atau mudah terbuka dan tanpa penjagaan, dan beberapa kondisi mendukung lainnya sehingga massa mudah terbentuk dan kemudian bergerak ke tujuan yang sama. Incentives mudah terbentuk karena dalam situasi kebersamaan (togetherness situation), tingkah laku seseorang akan cenderung sama dengan tingkah laku orang lainnya. Dengan kata lain, perlaku agresif dibentuk dan ditentukan oleh pengamatan individu terhadap perilaku lain, sehingga apabila kekerasan yang muncul dalam perilaku tersebut maka akan mudah menimbukan agresi imitatif dalam bentuk kekerasan yang menjalar.

Pinheiro Principles menyatakan bahwa pejabat yang berwenang harus diminta untuk melindungi, sedapat mungkin, terhadap penjarahan, pengrusakan, serta penguasaan secara sewenang-wenang dan ilegal, penempatan atau pemanfaatan harta atau hak milik orang-orang atau komunitas yang terdampak bencana. Upaya yang telah dilakukan pemerintah, baik pemerintah pusat maupun pemerintah daerah, untuk mengatasi penjarahan yang terjadi pascabencana alam ada dua: (1) penjaminan pemenuhan hak masyarakat, dan (2) perlindungan masyarakat dari dampak bencana. Kedua hal tersebut telah diatur dalam UU Nomor 24 tahun 2007 tentang Penanggulangan Bencana.

Penjaminan pemenuhan hak masyarakat dilakukan melalui penjagaan titik-titik pusat ekonomi dan Stasiun Pengisi Bahan Bakar (SPBU), menganjurkan toko-toko kelontong yang masih mempunyai persediaan makanan dan minuman untuk tetap buka dan melayani masyarakat, melakukan pengawalan pengambilan kebutuhan makanan di toko-toko kelontong, serta menginventarisir dan membayar pengambilan makanan oleh masyarakat pada saat itu juga. Perlindungan masyarakat dilakukan oleh pihak kepolisian dan TNI yang berkolaborasi menciptakan suasana aman melalui tindakan preemtif, preventif, dan represif. Tindakan preemtif dilakukan melalui bimbingan dan seruan guna menenangkan masyarakat yang panik. Tindakan preventif melalui penyampaian dan penegasan agar masyarakat tidak memanfaatkan peluang dengan melakukan kejahatan, dan represif berupa penangkapan terhadap pelaku penjarahan.

Pinheiro Principles menyatakan bahwa untuk meminimalkan pengrusakan atau penjarahan, negara harus mengembangkan prosedur untuk menginventarisir isi dari rumah, tanah, 
serta harta kekayaan yang diadukan dalam konteks program restitusi rumah, tanah, dan harta kekayaan. Faktor yang menyulitkan adalah bahwa kerusakan fisik yang luas ditambah dengan kemampuan penegakan hukum dan ketertiban yang lemah sering menyulitkan polisi mengumpulkan bukti-bukti atau melakukan investigasi. Hal inilah yang belum dilakukan Pemerintah Kota Palu. Inventarisir pun dilakukan pada masa pemulihan, bukan pada masa tanggap darurat. Selain itu tujuannya bukan untuk memberikan ganti rugi kepada masyarakat yang terkena dampak penjarahan melainkan lebih kepada ganti rgi kepemilihan lahan dan rumah.

Pemerintah juga belum menyediakan sarana untuk untuk menampung harapan dan keinginan masyarakat yang terkena dampak penjarahan. Belum ada jalan keluar dan umpan balik yang ditawarkan. Hal ini yang menyebabkan terjadinya kekecewaan dan penolakan yang berbuntut pada gugatan pengadilan sejumlah pengusaha korban penjarahan .

\section{PENUTUP}

\section{Kesimpulan}

Hasil temuan dan pembahasan diatas menyimpulkan bahwa:

1. Motif terjadinya penjarahan di Kota Palu pascabencana secara garis besar didasarkan pada dua hal, yaitu drives dan incentives. Drives didorong oleh timbulnya keinginan untuk memenuhi kebutuhan pangan, sementara incentives dipengaruhi oleh kondisi dan situasi tertentu dan menjadi penguat untuk melakukan penjarahan, seperti lemahnya pengawasan aparat, kondisi kacau balau, kondisi toko bahan pangan dan toko-toko lainnya dalam kondisi terbuka atau mudah terbuka dan tanpa penjagaan, dan beberapa kondisi mendukung lainnya di luar drives sehingga massa mudah terbentuk dan cenderung menghasilkan sikap dan tindakan yang lebih ekstrem yang berujung pada tindakan penjarahan secara massal.
2. Upaya yang telah dilakukan pemerintah untuk mengatasi penjarahan yang terjadi pascabencana alam pada 27 September 2018 di Kota Palu dilakukan dalam dua bentuk sesuai UU Nomor 24 tahun 2007 tentang Penanggulangan Bencana, yaitu (1) penjaminan pemenuhan hak masyarakat, dan (2) perlindungan masyarakat dari dampak bencana.

Penjaminan pemenuhan hak masyarakat dan pengungsi yang terkena bencana dilakukan melalui penjagaan titik-titik pusat ekonomi dan Stasiun Pengisi Bahan Bakar (SPBU), anjuran bagi toko-toko kelontong untuk tetap melayani masyarakat, mengawal pengambilan kebutuhan makanan di toko-toko kelontong, serta menginventarisir dan membayar pengambilan makanan oleh masyarakat pada saat itu juga. Di tingkat kepolisian, kepolisian Republik Indonesia bersama seluruh jajarannya di daerah Sulawesi Tengah melakukan tindakan preemtif, preventif, dan represif. Di tingkat pemerintah daerah, bantuan logistik mulai disebarkan di hari kedua di 412 titik pengungsian.

Perlindungan masyarakat dari dampak bencana dilakukan oleh pihak kepolisian dan TNI yang berkolaborasi menciptakan suasana aman melalui tindakan preemtif, preventif, dan represif. Tindakan preemtif dilakukan melalui bimbingan dan seruan guna menenangkan masyarakat yang panik. Tindakan preventif melalui penyampaian dan penegasan agar masyarakat tidak memanfaatkan peluang dengan melakukan kejahatan, dan represif berupa penangkapan terhadap pelaku penjarahan. Di tingkat pemerintah daerah, perlindungan masyarakat masih sebatas inventarisasi kerugian daerah dan belum ada tindak lanjut ganti rugi sebagaimana yang diharapkan oleh para korban penjarahan. 
Saran

Dari berbagai hasil temuan terkait manajemen bencana Kota Palu, saran yang dapat diberikan dalam penelitian ini antara lain:

1. Pascabencana, Gudang Bulog harus menjadi sentra utama pembagian kebutuhan pangan korban. Untuk itu Bulog harus memiliki database rumah tangga yang senantiasa terupdate sampai di tingkatan wilayah terkecil sehingga menjadi dasar bagi Bulog dalam pemberian bantuan pangan. Maksimal 3 jam setelah bencana, Bulog harus memiliki database jumlah rumah tangga yang memerlukan bantuan sehingga bantuan pangan dapat diturunkan tidak lebih dari 1x24 jam.

2. Guna meminimalkan kerugian yang terjadi akibat penjarahan, masyarakat umum dan pemilik usaha dapat mengikuti program asuransi pencurian. Asuransi jenis ini dapat menjadi salah satu upaya untuk melindungi properti individu dan perusahaan dari tindakan pencurian dan pembongkaran.

3. Selain bulog, pemerintah daerah di tahap kesiapsiagaan perlu memasukkan sentra-sentra logistik yang dapat diberdayakan pada saat bencana terjadi. Untuk itu perlu ada kerjasama, komitmen, dan jaminan persediaan pangan antara pemerintah daerah dan pengusaha logistik. Pihak kepolisian dan TNI juga ikut serta dalam kerjasama tersebut dan memberikan pengamanan bagi sentra logistik pada saat terjadi bencana.

4. Sebagai bagian dari pelayanan publik sekaligus pemberian jaminan dan perlindungan, pemerintah daerah sebaiknya membuka ruang pengaduan dan konsultasi terkait kerugian penjarahan yang dialami masyarakat. Pengaduan yang diterima selanjutnya ditindaklanjuti dan dijadikan bagian dari rencana kesiapsiagaan bencana.

5. Pemerintah dapat mengadopsi kebijakan yang dilakukan Pemerintah jepang terkait pengamanan properti milik warga. Kebijakan pengembalian barang hilang menjadi kunci tidak banyaknya kasus penjarahan. Pemerintah dapat memfasilitasi pemberian reward ketika masyarakat menemukan barang yang hilang atau dijarah dan mengembalikannya ke polisi untuk diteruskan ke pemilik.

\section{DAFTAR PUSTAKA}

Agung, Bintoro. Memahami Penjarahan yang Kerap Terjadi Selepas Bencana. 4 Oktober 2018. (Online), (https://www.cnnindonesia.com, diakses tanggal 11 Februari 2020)

Ahmadi, Abu. 2007. Psikologi Sosial. Edisi Revisi.Rineka Cipta. Jakarta

Aparat Diminta Tegas Cegah Penjarahan Meluas di Sulawesi Tengah. 1 November 2018. (Online, diakses tanggal 21 Januari 2020)

Harper, Erica. 2009. International Law and Standar Applicable in Natural Disaster Situation. Perlindungan HakHak Warga Sipil dalam Situasi Bencana. Terjemahan. Grasindo bekerjasama dengan Masyarakat Penanggulangan Bencana Indonesia, IDLO, Paln, dan World Vision Indonesia.

Syah, Kaharuddin. Kualifikasi Penjarahan Pasca Gempa Tsunami dan Likuifaksi di Kota Palu (Suatu Tinjauan Kriminologis). 2019. Maleo Law Journal. 29 September 2019. Jilid 3. Hal: 83-92.

Damarjati, Danu. Kaleidoskop 2018: Sore di Palu dan Donggala : Gempa Tsunami, dan Likuifaksi. 27 Desember 2018. (Online), (www.m.detik.com, diakses tanggal 21 Januari 2020)

Gabrillin, Abba. Kronologi Kepanikan Narapidana di Palu dan Donggala, Air Tanah Merembes hingga Pembakaran. 1 Oktober 2018. (Online) (www.kompas.com, diakses tanggal 21 Januari 2020)

Hidayat, Dody, et.al. 2013. Gempa : Kumpulan Artikel Ilmu dan Teknologi Majalah TEMPO. Tempo Publishing, Pusat Daya dan Analisa TEMPO.

Maghfiroh, Aisyatul. 2019. Studi 
Komparasi Tindak Pidana Penjarahan di saat Bencana Alam dalam Tinjauan Hukum Pidana Islam dan Hukum Pidana Positif. Skripsi. Universitas Islam Negeri Sunan Ampel. Fakultas Syariah dan Hukum.

Mulyadi, Seto. Penjarahan, Bencana Moral Pascabencana Alam. 2 Oktober 2018. (Online), (https:// www.beritasatu.com/opini, diakses tanggal 10 Februari 2020).

Pembelajaran di Balik Aksi Penjarahan Pascagempa Palu. 3 Januari 2019. (Online), (http:// theconservation.com, diakses tanggal 10 Februari 2020)

Putusan Perdata Gugatan Nomor 21/ Pdt.G/2019/PN Pal

Samad, Muhammad Ahsan. Kajian Fenomena

Pascabencana di Kota Palu. (Online), (https:// www.academia.edu, diakses tanggal 10 Februari 2020)

Sears, David O, dkk. 1992. Psikologi Sosial. Edisi Kelima. Jilid 1. Alih Bahasa: Michael Adryanto. Erlangga. Jakarta

Sompotan, Armstrong F. 2012. Struktur Geologi Sulawesi. Perpustakaan Sains Kebumian. Teknologi Bandung.

Tantri, Erlita. 2016. Manajemen dan Pengurangan Risiko Bencana di Tiongkok: Gempa Sichuan 2008. Jurnal Kajian Wilayah. Vol. 7 No. 1, Hal. 45 - 57

Undang-Undang Republik Indonesia Nomor 24 Tahun 2007 tentang Penanggulangan Bencana

Wiwoho, Laksono Hari. Apa yang Terjadi dengan Bantuan Kemanusiaan di Palu dan Donggala? 23 Oktober 2018. (Online), (www.kompas.com, diakses tanggal 25 Januari 2020)

Daniel, Joseph Robert Penjelasan di Balik Aksi Penjarahan Pascagempa Palu. 4 Januari 2019. (online), (https:// sains.kompas.com, diakses tanggal 10 Februari 2020).

Mengapa Ada Korban Gempa Tsunami Palu yang Malah Menjarah Televisi? (online), (https://sains.kompas.com, diakses tanggal 10 Februari 2020) 